\title{
FORMS AND ACCUMULATION OF COPPER AND ZINC IN A SANDY TYPIC HAPLUDALF SOIL AFTER LONG-TERM APPLICATION OF PIG SLURRY AND DEEP LITTER ${ }^{(1)}$
}

\author{
Tadeu Luis Tiecher ${ }^{(2)}$, Carlos Alberto Ceretta $^{(3)}$, Jucinei José Comin ${ }^{(4)}$, Eduardo \\ Girotto $^{(5)}$, Alcione Miotto ${ }^{(6)}$, Marcel Pires de Moraes ${ }^{(7)}$, Lucas Benedet ${ }^{(8)}$, Paulo Ademar \\ Avelar Ferreira ${ }^{(9)}$, Cledimar Rogério Lorenzi ${ }^{(6)}$, Rafael da Rosa Couto $^{(8)}$ \& Gustavo \\ Brunetto $^{(3)}$
}

\section{SUMMARY}

Successive applications of pig slurry and pig deep litter may lead to an accumulation of copper $(\mathrm{Cu})$ and zinc $(\mathrm{Zn})$ fractions in the soil profile. The objective of this study was to evaluate the $\mathrm{Cu}$ and $\mathrm{Zn}$ forms and accumulation in a Sandy Typic Hapludalf soil after long-term application of pig slurry and deep litter. In March 2010, eight years after initiating an experiment in Braço do Norte, Santa Catarina (SC), Brazil, on a Sandy Typic Hapludalf soil, soil samples were collected from the 0-2.5, 2.5-5.0, 5-10 and 10-15 cm layers in treatments consisting of no manure application (control) and with applications of pig slurry and deep litter at two levels: the single and double rate of $\mathrm{N}$ requirement for maize and black oat

(1) Study partially funded by the Social Technologies Project for Water Management (TSGA), the Santa Catarina Research Foundation (FAPESC) and the National Committee of Technological and Scientific Development (CNPq). Received for publication on August 28, 2012 and approved on March 18, 2013.

${ }^{(2)}$ Agronomist, Master's degree candidate in the Graduate Studies Program in Soil Science (PPGCS) of the Universidade Federal de Santa Maria (UFSM). Rural Sciences Center (CCR), Soil Department (DS). Postal Box 221. CEP 97105-900 Santa Maria (RS), Brazil. Capes scholarship holder. E-mail: tadeu.t@hotmail.com

(3) Agronomist, Doctor, Professor of the DS, UFSM. Fellowship holder in Research productivity of the CNPq. E-mail: carlosceretta@ufsm.br; brunetto.gustavo@gmail.com

(4) Agronomist, Doctor, Professor of the Graduate Studies Program in Agroecosystems (PGA) and of the Rural Engineering Department (ENR) of the Universidade Federal de Santa Catarina (UFSC). CCA, ENR, UFSC, Itacorubi. CEP 88034-000 Florianópolis (SC), Brazil. E-mail: jcomin@cca.ufsc.br

(5) Agronomist, Doctor, Professor of the Instituto Federal de Educação, Ciência e Tecnologia do Rio Grande do Sul, Ibiruba (RS). Rua Erly de Almeida Lima, 600/201. CEP 97105-120 Santa Maria (RS), Brazil. E-mail: girottosolos@gmail.com

(6) Agronomist, Master, Doctoral candidate of the PPGCS of UFSM, CCR, DS. Capes fellowship holder. E-mail: alcionemiotto@gmail.com; lourenzicr@gmail.com

(7) Student in the Agronomy Course of UFSC, CCA, ENR. E-mail: marcelpmoraes@gmail.com

(8) Agronomist, Doctoral candidate in Environmental Engineering (PPGEA) from UFSC. CCA, ENR, Itacorubi. Capes fellowship holder. E-mail: lucas_benedet@hotmail.com,rrccouto@hotmail.com

(9) Agronomist, Doctor, Post doctoral candidate of the PPGCS of UFSM. CCR, DS. Fellowship holder of the PNPD of CAPES. Email: ferreira.aap@gmail.com 


\begin{abstract}
succession. The soil was dried, ground in an agate mortar and analyzed for $\mathrm{Cu}$ and Zn contents by $0.01 \mathrm{~mol} \mathrm{~L}^{-1}$ EDTA and chemically fractionated to determine $\mathrm{Cu}$ and $\mathrm{Zn}$. The applications of Pig deep litter and slurry at doses equivalent to $90 \mathrm{~kg}$ $\mathrm{ha}^{-1} \mathrm{~N}$ increased the contents of available $\mathrm{Cu}$ and $\mathrm{Zn}$ in the surface soil layer, if the double of this dose was applied in pig deep litter or double this dose in pig slurry, $\mathrm{Cu}$ and $\mathrm{Zn}$ migrated to a depth of $15 \mathrm{~cm}$. Copper is accumulated mainly in the organic and residual fractions, and zinc preferentially in the fraction linked to clay minerals, especially in the surface soil layers.
\end{abstract}

Index terms: manure, trace elements, chemical fractionation, environmental contamination.

\title{
RESUMO: FORMAS E ACÚMULO DE COBRE E ZINCO EM UM ARGISSOLO VERMELHO COM HISTÓRICO DE APLICAÇÃO DE DEJETO LÍQUIDO E CAMA SOBREPOSTA DE SUÍNOS
}

\begin{abstract}
As aplicações sucessivas de dejetos líquidos e cama sobreposta de suínos podem provocar o acúmulo de frações de cobre (Cu) e zinco ( $\mathrm{Zn}$ ) no perfil do solo. Este trabalho objetivou avaliar as formas e o acúmulo de Cu e Zn em um Argissolo Vermelho com histórico de aplicação de dejetos líquidos e cama sobreposta de suínos. Em março de 2010, após oito anos da instalação de um experimento localizado no município de Braço do Norte, Santa Catarina, SC, sobre um Argissolo Vermelho, foram coletadas amostras de solo nas camadas de 0-2,5; 2,5-5,0; 5-10; e 10-15 cm, em tratamentos sem a aplicação de dejetos e com a aplicação de dejetos líquidos de suinos e de cama sobreposta de suínos em duas doses para suprir uma e duas vezes a necessidade de $N$ para a sucessão milho e aveia preta. $O$ solo foi seco, moído em gral de pedra ágata e submetido à análise dos teores de Cu e Zn por EDTA 0,01 mol L-1 e ao fracionamento químico de Cu e Zn. A aplicação de cama sobreposta de suinos e dejetos líquidos de suínos aumentou os teores de Cu e Zn disponíveis na camada superficial do solo; entretanto, quando se aplicaram

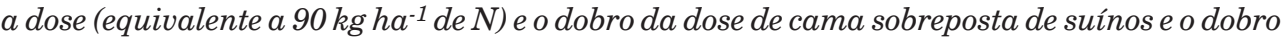
da dose de dejetos líquidos de suínos o Cu e o Zn migraram até $15 \mathrm{~cm}$ de profundidade. $\mathrm{OCu}$ no solo é acumulado especialmente na fração orgânica e residual e o $\mathrm{Zn}$, preferencialmente na fração ligada aos argilominerais, especialmente nas camadas mais superficiais.
\end{abstract}

Termos de indexação: esterco, elementos-traço, fracionamento químico, contaminação ambiental.

\section{INTRODUCTION}

Pig slurry, generated from washing out the stalls with water, and pig deep litter, a residue from raising pigs on a layer of organic material, normally consisting of wood chips or straw from crops, has been used as a source of nutrients for crops in management systems such as no-tillage. The quantity of pig slurry or deep litter to be applied must be determined based on the dry matter percentage, nutrient concentration, and by the efficiency index. This index is related to the total quantity of nutrients contained in the manure which may be transformed from the organic to mineral form after soil application (CQFS-RS/SC, 2004). Nevertheless, due to the large volume of manure produced on pig raising properties, manure applications are carried out repeatedly. Thus, over the years, one expects an increase in the soil contents of nutrient such as nitrogen $(\mathrm{N})$, phosphorus $(\mathrm{P})$, potassium (K), calcium (Ca) and magnesium $(\mathrm{Mg})$ (Ceretta et al., 2010; Guardini et al., 2012), but also in trace elements, particularly of copper $(\mathrm{Cu})$ and zinc
(Zn) (Girotto et al., 2010; Popovic \& Jensen, 2012), which are transferred from pig feed to manure.

In the soil, $\mathrm{Cu}$ and $\mathrm{Zn}$ are retained by physicalchemical bonds, and their lability depends on the ligand, especially on the content of clay minerals, iron (Fe) oxides and hydroxides, aluminum (Al) and manganese $(\mathrm{Mn})$, carbonates, and organic matter (McBride, 1994; Bradl, 2004), but also on the $\mathrm{pH}$ value of the soil (Bradl, 2004), cation exchange capacity (CTC) and the quality of organic matter. Therefore, these factors define $\mathrm{Cu}$ and $\mathrm{Zn}$ adsorption in the soil and are therefore found in different fractions in the soil, since naturally they are adsorbed at different energy levels (Casali et al., 2008; Girotto et al., 2010). However, the increase of $\mathrm{Cu}$ and $\mathrm{Zn}$ contents in the soil because of frequent pig slurry and deep litter applications may affect the distribution of their fractions in the soil. Normally, $\mathrm{Cu}$ and $\mathrm{Zn}$ adsorption in the soil occurs primarily in the most avid binding sites and then the remaining trace elements are redistributed in fractions bound with less energy with, consequently, greater availability and mobility. Thus, 
frequent manure applications may increase the quantity of soluble and exchangeable $\mathrm{Cu}$ and $\mathrm{Zn}$ fractions in the soil, creating a risk of potential toxicity for plants, but also of potential water contamination, by transfer in runoff on the soil surface and leaching through the profile (Ceretta et al., 2010).

Various chemical methods are used in the laboratory to estimate the availability of elements that are potentially toxic to plants and microorganisms and their mobility in the soil profile. Most commonly, extractions are made with chemical products in an isolated manner, such as diluted acids, saline solutions $\left(\mathrm{CaCl}_{2}, \mathrm{MgCl}_{2}, \mathrm{NH}_{4} \mathrm{OAc}\right)$ and especially chelating agents, such as diethylene triamine pentaacetic acid (DTPA) and ethylenediamine tetraacetic acid (EDTA) (Schramel et al., 2000). However, for some soils, the EDTA may be limited to estimate the trace element contents that are potentially toxic for plants or leachable (Chaignon \& Hinsinger, 2003). Thus, the data of availability of trace elements such as $\mathrm{Cu}$ and $\mathrm{Zn}$, obtained by a single analysis method such as EDTA, may be improved by evaluation with chemical fractionation of $\mathrm{Cu}$ and $\mathrm{Zn}$ in the soil. This fractionation consists of sequentially applied chemical extractors, removing the $\mathrm{Cu}$ and $\mathrm{Zn}$ from the most labile to the most stable fractions (Tessier et al., 1979; Girotto et al., 2010). It is thus possible to separate the total quantity of trace element in the soils or sediments into bioavailable (soluble in water and exchangeable), potentially bioavailable (linked to clay minerals, oxides, carbonates, and organic matter) and residual (mineral structure) fractions (Tessier et al., 1979). By this technique, it was observed, especially in soils receiving long-term $\mathrm{Cu}$ and $\mathrm{Zn}$ application via pig slurry and sewage sludge, that these two trace elements accumulate in the soil; $\mathrm{Cu}$ mainly in the organic fraction and $\mathrm{Zn}$ in the clay mineral fraction (Girotto et al., 2010). However, studies on soils after long-term application of pig deep litter are scarce in Brazilian literature. The objective of this study was to evaluate $\mathrm{Cu}$ and $\mathrm{Zn}$ forms and accumulation in a Sandy Typic Hapludalf after long-term application of pig slurry and deep litter.

\section{MATERIAL AND METHODS}

The experiment was carried out on a swine farm in Braço do Norte, a municipality in the south of the State of Santa Catarina (SC), in southern Brazil (Latitude 28 $8^{\circ}$ 14' 20.7'; Longitude $49^{\circ} 13^{\prime} 55.5^{\prime}$; $300 \mathrm{~m}$ asl). The climate in the region is humid sub-tropical (Cfa), with an annual average temperature of $18.7^{\circ} \mathrm{C}$ and annual average rainfall of $1,471 \mathrm{~mm}$. The soil on the farm was a Sandy Typic Hapludalf (Soil Survey Staff, 1999) (Table 1). In December 2002, in a naturalized pasture area of predominantly Paspalum notatum, Paspalum plicatulum, Eryngium ciliatum, and Stylosanthes montevidensis, after long-term,
Table 1. Main physical and chemical characteristics of the soil prior to the experiment, in the 0-10 cm layer

\begin{tabular}{lc}
\hline Characteristic & $\mathbf{0 - 1 0} \mathbf{~ c m}$ \\
\hline Clay $\left(\mathrm{g} \mathrm{kg}^{-1}\right)^{(1)}$ & 330 \\
Organic matter $\left(\mathrm{g} \mathrm{kg}^{-1}\right)^{(1)}$ & 33.0 \\
$\mathrm{pH}\left(\mathrm{H}_{2} \mathrm{O}\right)^{(2)}$ & 5.1 \\
$\mathrm{Al}^{3+}\left(\mathrm{cmol}_{\mathrm{c}} \mathrm{dm}^{-3}\right)^{(2)}$ & 0.8 \\
$\mathrm{Mg}^{2+}\left(\mathrm{cmol}_{\mathrm{c}} \mathrm{dm}^{-3}\right)^{(2)}$ & 0.8 \\
$\mathrm{Ca}^{2+}\left(\mathrm{cmol}_{\mathrm{c}} \mathrm{dm}^{-3}\right)^{(2)}$ & 3.0 \\
$\mathrm{P}\left(\mathrm{mg} \mathrm{dm}^{-3}\right)^{(2)}$ & 19.0 \\
$\left.\mathrm{~K}(\mathrm{mg} \mathrm{dm})^{-3}\right)^{(2)}$ & 130 \\
$\left.\mathrm{CEC} \mathrm{pH} 7.0_{(\mathrm{cmol}} \mathrm{dm}^{-3}\right)^{(3)}$ & 11.9 \\
$\mathrm{Al} \mathrm{saturation}(\%)^{(3)}$ & 16.13 \\
Base saturation $(\%)^{(3)}$ & 41.7 \\
\hline
\end{tabular}

(1) Embrapa (1997). ${ }^{(2)}$ Tedesco et al. (1995). ${ }^{(3)}$ CQFS-RS/SC (2004).

occasional application of pig slurry to the soil surface, $6 \mathrm{Mg} \mathrm{ha}^{-1}$ of limestone was applied (total neutralizing power $=87.5 \%$ ) on the soil surface without incorporation to raise water $\mathrm{pH}$ to 6.0 (CFS-RS/SC, 1994). In January 2003 , the pasture was desiccated and five treatments were established: control (C); annual fertilization with pig slurry rates of 90 and $180 \mathrm{~kg} \mathrm{ha}^{-1} \mathrm{~N}$ (PS90 and PS180) and annual fertilization with deep litter rates of 90 and $180 \mathrm{~kg} \mathrm{ha}^{-1} \mathrm{~N}$ (DL90 and DL180). The recommended $\mathrm{N}$ rate for the pig slurry and deep litter treatments was $90 \mathrm{~kg} \mathrm{ha}^{-1} \mathrm{~N}_{\text {year }}^{-1}$ for Zea mays and Avena strigosa succession in a no-tillage system (CFSRS/SC, 1994; CQFS-RS/SC, 2004). To calculate manure rates, the total $\mathrm{N}$ content of each manure type was used and the residual effect of this material on $\mathrm{N}$ availability in the second year was not considered. The dry matter and quantity of PS and DL applied are shown in table 2; however, over the years, the $\mathrm{Cu}$ and $\mathrm{Zn}$ contents in PS and DL were not determined. The residues were the only nutrient source applied to the system of crop succession over the years. The experiment was set up in a randomized block design with three replications, on experimental plots of $27 \mathrm{~m}^{2}(4.5 \times 6.0 \mathrm{~m})$. Pig slurry was applied 32 times during the experimental period from 2002 to 2010 (four applications per year during Zea mays and Avena strigosa development). The residue was applied to the soil surface four times a year: before sowing corn, 51 and 95 days after sowing corn and 15 days after sowing black oat. In the same period (2002-2010), deep litter was applied eight times on the soil surface, around 15 to 30 days before sowing corn.

\section{Soil collection and copper and zinc analysis in the soil profile}

In March 2010, a trench (40 x 40 x $40 \mathrm{~cm})$ was dug in the center of each experimental unit and soil was sampled (layers $0-2.5,2.5-5,5-10,10-15,15-20$ and $20-30 \mathrm{~cm}$ ). This soil was air-dried, ground in an 
Table 2. Dry matter and rate of pig slurry (PS) and deep litter (DL) applied during the experiment (2002-2010)

\begin{tabular}{|c|c|c|c|}
\hline Source & Year & Dry matter & Rate applied \\
\hline & & $\%$ & $\mathrm{~m}^{3} \mathrm{ha}^{-1}$ \\
\hline \multirow[t]{8}{*}{ PS90 } & 2003 & 2.94 & 20.0 \\
\hline & 2004 & 3.00 & 24.4 \\
\hline & 2005 & 1.63 & 78.5 \\
\hline & 2006 & 2.54 & 59.5 \\
\hline & 2007 & 2.32 & 63.3 \\
\hline & 2008 & 2.10 & 67.0 \\
\hline & 2009 & 0.20 & 176.0 \\
\hline & 2010 & 3.28 & 49.5 \\
\hline \multirow[t]{9}{*}{ PS180 } & 2003 & 2.94 & 40.6 \\
\hline & 2004 & 3.00 & 48.8 \\
\hline & 2005 & 1.63 & 157.0 \\
\hline & 2006 & 2.54 & 119.0 \\
\hline & 2007 & 2.32 & 126.6 \\
\hline & 2008 & 2.10 & 134.0 \\
\hline & 2009 & 0.20 & 352.0 \\
\hline & 2010 & 3.28 & 99.0 \\
\hline & & & $\mathrm{Mg} \mathrm{ha}^{-1}$ \\
\hline \multirow[t]{8}{*}{ DL90 } & 2003 & 69.20 & 13.0 \\
\hline & 2004 & 38.10 & 44.1 \\
\hline & 2005 & 43.80 & 20.9 \\
\hline & 2006 & 41.10 & 23.7 \\
\hline & 2007 & 39.00 & 25.6 \\
\hline & 2008 & 61.00 & 10.7 \\
\hline & 2009 & 69.90 & 8.1 \\
\hline & 2010 & 45.00 & 20.0 \\
\hline \multirow[t]{8}{*}{ DL180 } & 2003 & 69.20 & 26.0 \\
\hline & 2004 & 38.10 & 88.2 \\
\hline & 2005 & 43.80 & 41.8 \\
\hline & 2006 & 41.10 & 47.4 \\
\hline & 2007 & 39.00 & 51.2 \\
\hline & 2008 & 61.00 & 21.4 \\
\hline & 2009 & 69.90 & 16.2 \\
\hline & 2010 & 45.00 & 40 \\
\hline
\end{tabular}

agate mortar and stored in three portions. The first part of the soil was analyzed for physical properties such as clay, sand and silt (Embrapa, 1997), as well as chemical properties, e.g., total organic carbon content (Embrapa, 1997), water $\mathrm{pH}$; exchangeable $\mathrm{Ca}$, $\mathrm{Mg}$ and $\mathrm{Al}$; exchangeable $\mathrm{K}$, and available $\mathrm{P}$ (Tedesco et al., 1995); these analysis results were published earlier by Guardini et al. (2012). The second sample portion was analyzed for $\mathrm{Cu}(\mathrm{CuEDTA})$ and $\mathrm{Zn}$ levels (ZnEDTA) (Chaignon et al., 2003). The third soil portion was chemically fractionated and $\mathrm{Cu}$ and $\mathrm{Zn}$ contents determined (Tessier et al., 1979). In triplicate, $1 \mathrm{~g}$ of soil was transferred to $50 \mathrm{~mL}$ Falcon polypropylene centrifuge tubes to which the following extractors were applied in sequence: 1) Soluble fraction: $8 \mathrm{~mL}$ of Mill-Q water; 2) Exchangeable fraction: $8 \mathrm{~mL}$ of $1.0 \mathrm{~mol} \mathrm{~L}^{-1} \mathrm{MgCl}_{2}$ solution at $\mathrm{pH}$ 7.0 ; 3) Fraction bonded to clay minerals: $20 \mathrm{~mL}$ of the solution $0.04 \mathrm{~mol} \mathrm{~L}^{-1} \mathrm{NH}_{2} \mathrm{OHHCl}$ in $25 \%(\mathrm{v} / \mathrm{v})$ $\mathrm{CH}_{3} \mathrm{COOH}$ at $\mathrm{pH} 2.0$; 4) Fraction linked to organic matter: $3 \mathrm{~mL}$ of $0.02 \mathrm{~mol} \mathrm{~L}^{-1} \mathrm{HNO}_{3}$ solution $+8 \mathrm{~mL}$ of $30 \% \mathrm{H}_{2} \mathrm{O}_{2}$ adjusted to $\mathrm{pH} 2.0$ with $\mathrm{HNO}_{3} ; 5$ ) Residual fraction: total digestion with $\mathrm{HF}$ and $\mathrm{HClO}_{4}$. Total $\mathrm{Cu}$ and $\mathrm{Zn}$ were analyzed in non-fractioned $1 \mathrm{~g}$ soil samples (Tessier et al., 1979). After each extraction of the chemical fractionation, the samples were centrifuged at 3,500 rpm for $30 \mathrm{~min}$ and an aliquot of the supernatant was filtered and set aside for determination of the $\mathrm{Cu}$ and $\mathrm{Zn}$ content. Determination of the $\mathrm{Cu}$ and $\mathrm{Zn}$ contents in the solution was performed by Inductively Coupled Plasma Atomic Emission Spectrometry ICP-AES (Perkin Elmer, Optima 2100 DV). Determination of $\mathrm{Cu}$ and $\mathrm{Zn}$ extracted from other fractions was performed by Atomic Absorption Spectrometry. The glassware of all analyses was cleaned with $10 \%$ $\mathrm{HNO}_{3}$ and maintained in this acid for at least $24 \mathrm{~h}$; after this period, the recipients were washed three times with deionized water.

\section{Statistical data treatment}

The contents of CuEDTA and ZnEDTA as well as the of the forms of the two elements were subjected to analysis of variance by the statistical program SISVAR (Ferreira, 2003), with the model $y_{i j k}=\mu+B_{i}+W_{j}+$ $\operatorname{error}_{\mathrm{a}}(\mathrm{i}, \mathrm{j})+\mathrm{Dk}+\operatorname{error}_{\mathrm{b}}(\mathrm{i}, \mathrm{k})+\mathrm{W} \cdot \mathrm{D}_{\mathrm{jk}}=\operatorname{error}_{\mathrm{c}}(\mathrm{i}, \mathrm{j}, \mathrm{k})$, where $\mu=$ general mean ; $\mathrm{B}=$ treatments $(\mathrm{i}=1,2,3,4,5)$; $\mathrm{D}=\operatorname{depth}(\mathrm{j}=1,2,3,4)$ and error $=$ experimental error. When significant, the data were compared by the ScottKnott test $(\mathrm{p}<0.05)$.

\section{RESULTS}

\section{Available copper and zinc in the soil profile}

The natural contents of available $\mathrm{Cu}$ extracted by EDTA (CuEDTA) from the soil of the control treatment were $3.7 \mathrm{mg} \mathrm{kg}^{-1}$ in the $0-2.5,2.5-5.0$ and $5.0-10 \mathrm{~cm}$ layers, and $3.0 \mathrm{mg} \mathrm{kg}^{-1}$ in the $10-15 \mathrm{~cm}$ layer (Table 3 ). These contents were equal among the layers. On the other hand, the natural contents of available $\mathrm{Zn}$ extracted by EDTA (ZnEDTA) were 10.3, 7.4, 4.4 and $2.1 \mathrm{mg} \mathrm{kg}^{-1}$ in the $0-2.5,2.5-5.0,5.0-10$ and $10-15 \mathrm{~cm}$ layers, respectively (Table 3). In the PS90, PS180, DL90 and DL180 treatments, the greatest CuEDTA and ZnEDTA contents were observed in the surface layer, $0-2.5 \mathrm{~cm}$. Nevertheless, in all layers evaluated, i.e., to a depth of $15 \mathrm{~cm}$, CuEDTA and ZnEDTA contents were highest in DL180, treated with eight applications of pig deep litter between 2002 and 2010 . Likewise, in all layers of the DL90 treatment, CuEDTA and ZnEDTA contents were lower than in DL180, but higher than in the control and of PS90 and PS180. The CuEDTA contents obtained in the 0- 
Table 3. Copper (CuEDTA) and zinc (ZnEDTA) available in soil layers treated with pig slurry and deep litter applications for eight years

\begin{tabular}{|c|c|c|c|c|}
\hline \multirow{2}{*}{ Source } & \multicolumn{4}{|c|}{ Layer (cm) } \\
\hline & $0-2.5$ & 2.5-5.0 & $5.0-10$ & $10-15$ \\
\hline & \multicolumn{4}{|c|}{ Available $\mathrm{Cu}$ (CuEDTA) (mg kg$\left.{ }^{-1}\right)$} \\
\hline Control & $3.7 \mathrm{Ae}$ & $3.7 \mathrm{Ae}$ & $3.7 \mathrm{Ad}$ & $3.0 \mathrm{Ad}$ \\
\hline PS90 & 14.1 Ad & $9.0 \mathrm{Bd}$ & $5.5 \mathrm{Cd}$ & $2.3 \mathrm{Dd}$ \\
\hline PS180 & $29.0 \mathrm{Ac}$ & $17.5 \mathrm{Bc}$ & $11.3 \mathrm{Cc}$ & $6.2 \mathrm{Dc}$ \\
\hline DL90 & $54.7 \mathrm{Ab}$ & $37.8 \mathrm{Bb}$ & $25.1 \mathrm{Cb}$ & $10.2 \mathrm{Db}$ \\
\hline \multirow[t]{2}{*}{ DL180 } & $121.6 \mathrm{Aa}$ & $101.4 \mathrm{Ba}$ & $49.9 \mathrm{Ca}$ & $23.2 \mathrm{Da}$ \\
\hline & \multicolumn{4}{|c|}{ Available $\mathrm{Zn}$ (ZnEDTA) (mg kg$\left.{ }^{-1}\right)$} \\
\hline Control & $10.3 \mathrm{Ae}$ & $7.4 \mathrm{Ae}$ & $4.4 \mathrm{Bd}$ & $2.1 \mathrm{Bd}$ \\
\hline PS90 & $30.4 \mathrm{Ad}$ & $14.3 \mathrm{Bd}$ & $6.0 \mathrm{Cd}$ & $2.1 \mathrm{Cd}$ \\
\hline PS180 & $62.5 \mathrm{Ac}$ & $31.8 \mathrm{Bc}$ & $18.4 \mathrm{Cc}$ & $8.1 \mathrm{Dc}$ \\
\hline DL90 & $182.5 \mathrm{Ab}$ & $85.5 \mathrm{Bb}$ & $47.7 \mathrm{Cb}$ & $9.9 \mathrm{Db}$ \\
\hline DL180 & $310.9 \mathrm{Aa}$ & $222.4 \mathrm{Ba}$ & $87.9 \mathrm{Ca}$ & $29.3 \mathrm{Da}$ \\
\hline
\end{tabular}

(1) Mean values followed by the same capital letter in the row (layer) and small letter in the column (source) are not significantly different (Scott-Knott test, $\mathrm{p}<0.05)$.

2.5 and 2.5-5.0 cm layers of the PS90 and PS180 treatments were lower than those observed in DL90 and DL180, but greater than in the control treatment (Table 3). In the 5.0-10 and 10-15 cm layers, the CuEDTA contents in PS180 continued lower than those observed in the DL90 and DL180 treatment, but exceeded those found in the PS90 and control treatment. In the 5.0-10 and 10-15 cm layers of these two treatments (PS90 and control), the CuEDTA contents were equal. On the other hand, the ZnEDTA contents in the 0-2.5 and 2.5-5.0 cm layer in the PS90 and PS180 treatment were lower than in the DL90 and DL180 treatment, but greater than in the control treatment, as observed for the CuEDTA contents. But in the 5.0-10 and 10-15 cm layers, the ZnEDTA content in the PS90 and PS180 treatment was lower than in DL90 and DL180, but the content in PS180 was greater than in PS90 and the control, which were equal in these two layers (5.0-10 and 10-15 cm).

\section{Copper fraction in the soil profile}

The copper contents in the soluble fraction in the control treatment were equal in all soil layers (Table 4). Copper contents in the soluble fraction increased to a depth of $10 \mathrm{~cm}$ in PS90 and in PS180, DL90 and DL180 the content increased to a depth of $5.0 \mathrm{~cm}$. Nevertheless, the $\mathrm{Cu}$ contents were highest in the soluble fraction in all layers in the DL180 treatment, followed by DL90, similarly to the CuEDTA and ZnEDTA contents (Table 3 ). Soluble Cu contents, in all soil layers of DL90 were higher than in the other treatments (control, PS90 and PS180). On the other hand, in the exchangeable $\mathrm{Cu}$ fraction, in PS90, contents were only high in the top soil layer $(0-2.5 \mathrm{~cm})$, but in PS180, the $\mathrm{Cu}$ contents in the exchangeable fraction increased to a depth of $10 \mathrm{~cm}$
(Table 4). In DL90 and DL180, the Cu contents in the exchangeable fraction were highest to a depth of $5.0 \mathrm{~cm}$. Nevertheless, in all layers, the greatest $\mathrm{Cu}$ contents in the exchangeable fraction were observed in DL180, in line with the $\mathrm{Cu}$ data in the soluble fraction.

Copper contents in the clay minerals and the organic matter fraction linked were equal in the layers evaluated in the control treatment, which agrees with the data obtained in the soluble Cu fraction (Table 4). In the $\mathrm{Cu}$ fraction linked to clay minerals and organic matter, the contents of the element in the PS180, DL90 and DL180 treatment were highest in the surface layer $(0-2.5 \mathrm{~cm})$. However, in the $\mathrm{Cu}$ fraction linked to organic matter in the PS90 treatment, the greatest contents of the element were observed to a depth of $5 \mathrm{~cm}$. In the $\mathrm{Cu}$ fraction linked to clay minerals and the organic matter, the greatest contents of the trace element, in all layers, were observed in the soil of DL180, which agrees with the results of soluble and exchangeable $\mathrm{Cu}$ (Table 4), followed by the contents observed in DL90. The Cu contents linked to clay minerals and the organic fraction, especially down to the 2.5-5 cm layer in the PS90 and PS180 treatment, were less than those observed in DL90 and DL180, but were greater than those observed in the control treatment.

The greatest $\mathrm{Cu}$ contents in the residual fraction, as well as in the total fraction, in the soil of the PS90, DL90 and DL180 treatments were observed in the 0$2.5 \mathrm{~cm}$ layer (Table 4). However, in the residual fraction of PS180, the greatest Cu contents were observed to a depth of $5 \mathrm{~cm}$. Nevertheless, in all layers, the $\mathrm{Cu}$ contents in the residual and total fraction were highest in DL180. Copper contents in the residual and total fraction in DL90 were lower than in DL180, 
Table 4. Forms of copper in soil layers treated with pig slurry and deep litter applications for eight years

\begin{tabular}{|c|c|c|c|c|}
\hline \multirow{2}{*}{ Source } & \multicolumn{4}{|c|}{ Layer (cm) } \\
\hline & $0-2.5$ & 2.5-5.0 & 5.0-10 & $10-15$ \\
\hline & \multicolumn{4}{|c|}{ Soluble (mg kg$\left.{ }^{-1}\right)$} \\
\hline Control & $0.10 \mathrm{Ad}^{(1)}$ & $0.11 \mathrm{Ad}$ & $0.10 \mathrm{Ad}$ & $0.13 \mathrm{Ac}$ \\
\hline PS90 & $0.16 \mathrm{Ad}$ & $0.17 \mathrm{Ad}$ & $0.13 \mathrm{Ad}$ & $0.07 \mathrm{Bd}$ \\
\hline PS180 & $0.53 \mathrm{Ac}$ & $0.41 \mathrm{Ac}$ & $0.29 \mathrm{Bc}$ & $0.18 \mathrm{Cc}$ \\
\hline DL90 & $0.70 \mathrm{Ab}$ & $0.64 \mathrm{Ab}$ & $0.48 \mathrm{Bb}$ & $0.36 \mathrm{Cb}$ \\
\hline \multirow[t]{2}{*}{ DL180 } & $1.32 \mathrm{Aa}$ & $1.66 \mathrm{Aa}$ & $0.92 \mathrm{Ba}$ & $0.66 \mathrm{Ca}$ \\
\hline & \multicolumn{4}{|c|}{ Exchangeable $\left(\mathrm{mg} \mathrm{kg}^{-1}\right)$} \\
\hline Control & $0.14 \mathrm{Be}$ & $0.23 \mathrm{Ad}$ & $0.28 \mathrm{Ac}$ & $0.28 \mathrm{Ab}$ \\
\hline PS90 & $0.68 \mathrm{Ab}$ & $0.40 \mathrm{Bc}$ & $0.25 \mathrm{Cc}$ & $0.11 \mathrm{Dc}$ \\
\hline PS180 & $0.39 \mathrm{Ad}$ & $0.25 \mathrm{Ad}$ & $0.44 \mathrm{Ab}$ & $0.10 \mathrm{Cc}$ \\
\hline DL90 & $0.57 \mathrm{Ac}$ & $0.52 \mathrm{Ab}$ & $0.33 \mathrm{Bc}$ & $0.14 \mathrm{Cc}$ \\
\hline \multirow[t]{2}{*}{ DL180 } & $0.92 \mathrm{Aa}$ & $1.06 \mathrm{Aa}$ & $0.69 \mathrm{Ba}$ & $0.37 \mathrm{Ca}$ \\
\hline & \multicolumn{4}{|c|}{$\mathrm{Cu}$-minerals $\left(\mathrm{mg} \mathrm{kg}^{-1}\right)$} \\
\hline Control & $1.37 \mathrm{Ae}$ & $1.26 \mathrm{Ae}$ & $1.15 \mathrm{Ae}$ & $1.15 \mathrm{Ad}$ \\
\hline PS90 & $4.35 \mathrm{Ad}$ & $3.44 \mathrm{Ad}$ & $2.32 \mathrm{Bd}$ & $1.19 \mathrm{Cd}$ \\
\hline PS180 & $11.90 \mathrm{Ac}$ & $7.84 \mathrm{Bc}$ & $5.06 \mathrm{Cc}$ & $2.86 \mathrm{Dc}$ \\
\hline DL90 & $17.83 \mathrm{Ab}$ & $16.29 \mathrm{Bb}$ & $11.72 \mathrm{Cb}$ & $4.84 \mathrm{Db}$ \\
\hline \multirow[t]{2}{*}{ DL180 } & $40.24 \mathrm{Aa}$ & $37.98 \mathrm{Ba}$ & $23.53 \mathrm{Ca}$ & $12.72 \mathrm{Da}$ \\
\hline & \multicolumn{4}{|c|}{$\mathrm{Cu}$-organic matter $\left(\mathrm{mg} \mathrm{kg}^{-1}\right)$} \\
\hline Control & $2.74 \mathrm{Ae}$ & $2.58 \mathrm{Ae}$ & $2.34 \mathrm{Ad}$ & $1.30 \mathrm{Ac}$ \\
\hline PS90 & $9.64 \mathrm{Ad}$ & $4.42 \mathrm{Bd}$ & $1.81 \mathrm{Cd}$ & $1.00 \mathrm{Cc}$ \\
\hline PS180 & $17.58 \mathrm{Ac}$ & $9.80 \mathrm{Bc}$ & $4.52 \mathrm{Cc}$ & $2.50 \mathrm{Dc}$ \\
\hline DL90 & $36.67 \mathrm{Ab}$ & $22.86 \mathrm{Bb}$ & $12.46 \mathrm{Cb}$ & $3.51 \mathrm{Db}$ \\
\hline \multirow[t]{2}{*}{ DL180 } & $79.94 \mathrm{Aa}$ & $62.13 \mathrm{Ba}$ & $22.68 \mathrm{Ca}$ & $8.82 \mathrm{Da}$ \\
\hline & \multicolumn{4}{|c|}{ Residue (mg kg-1) } \\
\hline Control & $5.99 \mathrm{Be}$ & $7.58 \mathrm{Ae}$ & $7.58 \mathrm{Ad}$ & $5.65 \mathrm{Bc}$ \\
\hline PS90 & $11.24 \mathrm{Ad}$ & $8.49 \mathrm{Bd}$ & $7.11 \mathrm{Cd}$ & $4.91 \mathrm{Dc}$ \\
\hline PS180 & $14.38 \mathrm{Ac}$ & $12.90 \mathrm{Ac}$ & $9.94 \mathrm{Bc}$ & $6.98 \mathrm{Cc}$ \\
\hline DL90 & $37.28 \mathrm{Ab}$ & $28.30 \mathrm{Bb}$ & $20.78 \mathrm{Cb}$ & $11.85 \mathrm{Db}$ \\
\hline \multirow[t]{2}{*}{ DL180 } & $65.85 \mathrm{Aa}$ & $54.24 \mathrm{Ba}$ & $25.10 \mathrm{Ca}$ & $14.42 \mathrm{Da}$ \\
\hline & \multicolumn{4}{|c|}{ Sum fractions $\left(\mathrm{mg} \mathrm{kg}^{-1}\right)$} \\
\hline Control & $10.34 \mathrm{Ae}$ & $11.77 \mathrm{Ae}$ & $11.45 \mathrm{Ad}$ & $8.51 \mathrm{Ad}$ \\
\hline PS90 & $26.08 \mathrm{Ad}$ & $16.91 \mathrm{Bd}$ & $11.62 \mathrm{Cd}$ & $7.28 \mathrm{Dd}$ \\
\hline PS180 & $44.79 \mathrm{Ac}$ & $31.19 \mathrm{Bc}$ & $20.25 \mathrm{Cc}$ & $12.61 \mathrm{Dc}$ \\
\hline DL90 & $93.05 \mathrm{Ab}$ & $68.61 \mathrm{Bb}$ & $45.77 \mathrm{Cb}$ & $20.70 \mathrm{Db}$ \\
\hline \multirow[t]{2}{*}{ DL180 } & $188.28 \mathrm{Aa}$ & $157.08 \mathrm{Ba}$ & $72.92 \mathrm{Ca}$ & $37.00 \mathrm{Da}$ \\
\hline & \multicolumn{4}{|c|}{ Total $\left.(\mathrm{mg} \mathrm{kg})^{-1}\right)$} \\
\hline Control & $8.40 \mathrm{Ae}$ & $8.95 \mathrm{Ae}$ & $8.40 \mathrm{Ad}$ & $8.40 \mathrm{Ad}$ \\
\hline PS90 & $26.81 \mathrm{Ad}$ & $19.82 \mathrm{Bd}$ & $12.30 \mathrm{Cd}$ & 6.99 Dd \\
\hline PS180 & $45.49 \mathrm{Ac}$ & $31.36 \mathrm{Bc}$ & $22.31 \mathrm{Cc}$ & $13.91 \mathrm{Dc}$ \\
\hline DL90 & $83.53 \mathrm{Ab}$ & $56.90 \mathrm{Bb}$ & $41.30 \mathrm{Cb}$ & $19.86 \mathrm{Db}$ \\
\hline DL180 & $185.15 \mathrm{Aa}$ & $157.91 \mathrm{Ba}$ & $69.68 \mathrm{Ca}$ & $36.18 \mathrm{Da}$ \\
\hline
\end{tabular}

(1) Mean values followed by the same capital letter in the row (layer) and small letter in the column (source) are not significantly different (Scott-Knott test, $\mathrm{p}<0.05$ ). 
but greater than in PS90 and PS180. Copper contents in the residual and total fraction in PS180 were higher than in PS90, but both were higher than in the control treatment.

Thus, according to the results presented (Table 4) and based on the data of Figure 1, it may be observed that in the soil of the control treatment, at all depths, the greatest percentage of $\mathrm{Cu}$ was found linked to the residual fraction, followed by the fraction linked to organic matter and the fraction linked to clay minerals, with the lowest percentages linked to the exchangeable fraction and in solution (Figure 1). Nevertheless, after the application of pig slurry (PS90 and PS180) and deep litter (DL90 and DL180), the percentage of $\mathrm{Cu}$ in the residual fraction diminished in comparison with the control treatment, especially in the two surface layers $(0-2.5$ and $2.5-5.0 \mathrm{~cm})$. Copper, particularly in these two layers, was also linked to the residual fraction, but increased especially the percentage linked to the organic fraction, although there was also an increase in the percentage linked to clay minerals, which was lower than the percentage linked to the organic fraction. However, in the deepest soil layers, $5.0-10$ and $10-15 \mathrm{~cm}$, in all treatments, the highest percentage of $\mathrm{Cu}$ was observed in the residual fraction, but especially in DL180, DL90 and PS180. Percentage of copper in the residual fraction decreased in comparison to the control treatment because the percentage of the trace element linked to organic matter and to the clay minerals increased. In the 5.0-10 cm layer in the DL180, DL90 and PS180 treatments, the percentages of $\mathrm{Cu}$ linked to organic matter were similar to the percentage of $\mathrm{Cu}$ linked to clay minerals, but in the $10-15 \mathrm{~cm}$ layer, the greatest percentage of $\mathrm{Cu}$ was found in the residual fraction, followed by the fraction linked to clay minerals and the organic fraction.

\section{Zinc fraction in the soil profile}

Zinc contents in the soluble and exchangeable fraction in the soil of the control treatment were equal in all layers evaluated (Table 5). In the PS90 treatment, the $\mathrm{Zn}$ content in the soluble fraction was equal in the layers, in agreement with the results obtained in the control treatment. However, in PS90 and DL90, the greatest Zn contents in the soluble and exchangeable fraction were observed in the surface layer $(0-2.5 \mathrm{~cm})$. On the other hand, in DL180, the highest soluble $\mathrm{Zn}$ contents were observed to a depth of $5 \mathrm{~cm}$, but in the exchangeable fraction, up to $2.5 \mathrm{~cm}$, which agrees with the results obtained in the PS90, PS180 and DL90 treatment. Nevertheless, especially in the $0-5.0$ and $5.0-10 \mathrm{~cm}$ layers, the soluble $\mathrm{Zn}$ contents were highest in DL180, which agrees with

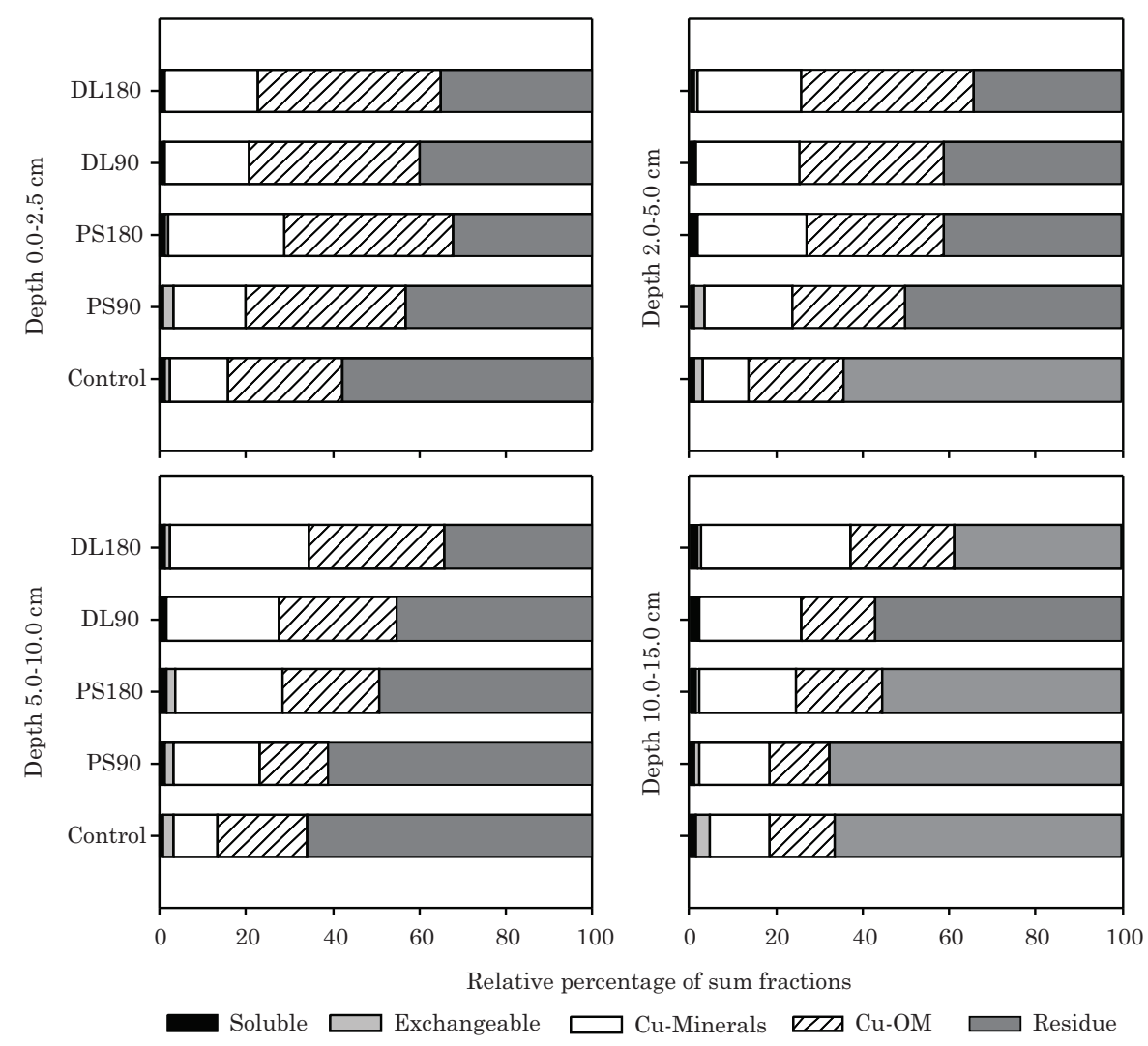

Figure 1. Relative percentage of copper in each fraction obtained in sequential extraction in relation to the sum of the quantity extracted in soil layers treated with pig slurry and deep litter applications for eight years. 
Table 5. Forms of zinc in soil layers treated with pig slurry and deep litter applications for eight years

\begin{tabular}{|c|c|c|c|c|}
\hline \multirow{2}{*}{ Source } & \multicolumn{4}{|c|}{ Layer (cm) } \\
\hline & $0-2.5$ & 2.5-5.0 & 5.0-10 & $10-15$ \\
\hline & \multicolumn{4}{|c|}{ Soluble $\left(\mathrm{mg} \mathrm{kg}^{-1}\right)$} \\
\hline Control & $0.10 \mathrm{Ab}^{(1)}$ & $0.09 \mathrm{Ac}$ & $0.11 \mathrm{Ac}$ & $0.19 \mathrm{Aa}$ \\
\hline PS90 & $0.13 \mathrm{Ab}$ & $0.12 \mathrm{Ac}$ & $0.11 \mathrm{Ac}$ & $0.09 \mathrm{Ab}$ \\
\hline PS180 & $0.41 \mathrm{Aa}$ & $0.34 \mathrm{Bb}$ & $0.30 \mathrm{Cb}$ & $0.23 \mathrm{Da}$ \\
\hline DL90 & $0.44 \mathrm{Aa}$ & $0.34 \mathrm{Bb}$ & $0.23 \mathrm{Cb}$ & $0.23 \mathrm{Ca}$ \\
\hline \multirow[t]{2}{*}{ DL180 } & $0.41 \mathrm{Aa}$ & $0.48 \mathrm{Aa}$ & $0.36 \mathrm{Ba}$ & $0.22 \mathrm{Ca}$ \\
\hline & \multicolumn{4}{|c|}{ Exchangeable $\left(\mathrm{mg} \mathrm{kg}^{-1}\right)$} \\
\hline Control & $1.80 \mathrm{Ad}$ & $1.54 \mathrm{Ad}$ & $1.50 \mathrm{Ad}$ & $1.16 \mathrm{Ad}$ \\
\hline PS90 & $5.33 \mathrm{Ac}$ & $3.01 \mathrm{Bc}$ & $1.90 \mathrm{Cc}$ & $0.87 \mathrm{Dc}$ \\
\hline PS180 & $20.03 \mathrm{Ab}$ & $13.64 \mathrm{Bb}$ & $8.24 \mathrm{Cb}$ & $4.93 \mathrm{Db}$ \\
\hline DL90 & $23.66 \mathrm{Aa}$ & $18.34 \mathrm{Ba}$ & $12.82 \mathrm{Ca}$ & $4.42 \mathrm{Db}$ \\
\hline \multirow[t]{2}{*}{ DL180 } & $17.95 \mathrm{Aa}$ & $15.88 \mathrm{Ba}$ & $10.88 \mathrm{Ca}$ & $6.05 \mathrm{Da}$ \\
\hline & \multicolumn{4}{|c|}{ Zn-minerals $\left(\mathrm{mg} \mathrm{kg}^{-1}\right)$} \\
\hline Control & $14.86 \mathrm{Ae}$ & $13.27 \mathrm{Ae}$ & $9.22 \mathrm{Bd}$ & $5.47 \mathrm{Bc}$ \\
\hline PS90 & $36.36 \mathrm{Ad}$ & $20.81 \mathrm{Bd}$ & $11.07 \mathrm{Cd}$ & $4.91 \mathrm{Dc}$ \\
\hline PS180 & $54.04 \mathrm{Ac}$ & $29.13 \mathrm{Bc}$ & $17.98 \mathrm{Cc}$ & $8.68 \mathrm{Dc}$ \\
\hline DL90 & $160.06 \mathrm{Ab}$ & $84.61 \mathrm{Bb}$ & $48.62 \mathrm{Cb}$ & $13.25 \mathrm{Db}$ \\
\hline \multirow[t]{2}{*}{ DL180 } & $270.24 \mathrm{Aa}$ & $204.72 \mathrm{Ba}$ & $81.91 \mathrm{Ca}$ & $32.34 \mathrm{Da}$ \\
\hline & \multicolumn{4}{|c|}{ Zn-organic matter $\left(\mathrm{mg} \mathrm{kg}^{-1}\right)$} \\
\hline Control & $0.88 \mathrm{Ad}$ & $0.78 \mathrm{Ac}$ & $0.54 \mathrm{Ac}$ & $0.12 \mathrm{Bb}$ \\
\hline PS90 & $1.85 \mathrm{Ac}$ & $1.15 \mathrm{Bc}$ & $0.39 \mathrm{Cc}$ & $0.06 \mathrm{Cb}$ \\
\hline PS180 & $1.90 \mathrm{Ac}$ & $1.27 \mathrm{Bc}$ & $0.73 \mathrm{Cc}$ & $0.49 \mathrm{Ca}$ \\
\hline DL90 & $5.86 \mathrm{Ab}$ & $3.05 \mathrm{Bb}$ & $1.74 \mathrm{Cb}$ & $0.63 \mathrm{Da}$ \\
\hline \multirow[t]{2}{*}{ DL180 } & $14.45 \mathrm{Aa}$ & $9.99 \mathrm{Ba}$ & $2.43 \mathrm{Ca}$ & $0.85 \mathrm{Da}$ \\
\hline & \multicolumn{4}{|c|}{ Residue (mg kg-1) } \\
\hline Control & $24.99 \mathrm{Ab}$ & $28.21 \mathrm{Ab}$ & $30.24 \mathrm{Aa}$ & $27.00 \mathrm{Ab}$ \\
\hline PS90 & $29.90 \mathrm{Ab}$ & $26.27 \mathrm{Ab}$ & $31.25 \mathrm{Aa}$ & $28.41 \mathrm{Ab}$ \\
\hline PS180 & $31.64 \mathrm{Ab}$ & $28.26 \mathrm{Ab}$ & $29.61 \mathrm{Aa}$ & $23.23 \mathrm{Ab}$ \\
\hline DL90 & $47.47 \mathrm{Aa}$ & $33.31 \mathrm{Ba}$ & $35.97 \mathrm{Ba}$ & $35.02 \mathrm{Ba}$ \\
\hline \multirow[t]{2}{*}{ DL180 } & $48.03 \mathrm{Aa}$ & $43.15 \mathrm{Aa}$ & $30.18 \mathrm{Ba}$ & $38.76 \mathrm{Aa}$ \\
\hline & \multicolumn{4}{|c|}{ Sum fractions $\left(\mathrm{mg} \mathrm{kg}^{-1}\right)$} \\
\hline Control & $42.63 \mathrm{Ae}$ & $43.90 \mathrm{Ad}$ & $41.61 \mathrm{Ad}$ & $33.94 \mathrm{Ac}$ \\
\hline PS90 & $73.58 \mathrm{Ad}$ & $51.36 \mathrm{Bd}$ & $44.73 \mathrm{Bd}$ & $34.34 \mathrm{Cc}$ \\
\hline PS180 & $108.05 \mathrm{Ac}$ & $72.65 \mathrm{Bc}$ & $56.86 \mathrm{Cc}$ & $37.56 \mathrm{Dc}$ \\
\hline DL90 & $237.48 \mathrm{Ab}$ & $139.66 \mathrm{Bb}$ & $99.39 \mathrm{Cb}$ & $53.56 \mathrm{Db}$ \\
\hline \multirow[t]{2}{*}{ DL180 } & $351.08 \mathrm{Aa}$ & $274.22 \mathrm{Ba}$ & $125.76 \mathrm{Ca}$ & $78.22 \mathrm{Da}$ \\
\hline & \multicolumn{4}{|c|}{ Total $\left(\mathrm{mg} \mathrm{kg}^{-1}\right)$} \\
\hline Control & $43.31 \mathrm{Ae}$ & $34.77 \mathrm{Ad}$ & $35.67 \mathrm{Ac}$ & $35.40 \mathrm{Aa}$ \\
\hline PS90 & $70.86 \mathrm{Ad}$ & $55.67 \mathrm{Ac}$ & $41.29 \mathrm{Bc}$ & $31.53 \mathrm{Ba}$ \\
\hline PS180 & $106.86 \mathrm{Ac}$ & $64.64 \mathrm{Bc}$ & $53.38 \mathrm{Bc}$ & $39.15 \mathrm{Ca}$ \\
\hline DL90 & $214.95 \mathrm{Ab}$ & $124.54 \mathrm{Bb}$ & $92.19 \mathrm{Cb}$ & $45.68 \mathrm{Da}$ \\
\hline DL180 & $378.02 \mathrm{Aa}$ & $291.87 \mathrm{Ba}$ & $120.26 \mathrm{Ca}$ & $54.86 \mathrm{Da}$ \\
\hline
\end{tabular}

(1) Mean values followed by the same capital letter in the row (layer) and small letter in the column (source) are not significantly different (Scott-Knott test, $\mathrm{p}<0.05$ ). 
the $\mathrm{Cu}$ data (Table 4). In the 0-2.5 and 10-15 cm layers, the soluble $\mathrm{Zn}$ contents were highest in the PS180, DL90 and DL180. It is worth emphasizing that in the 2.5-5.0 and 5-10 cm layers, the soluble $\mathrm{Zn}$ contents in PS180 and DL90 were equal, but lower than in DL180 and higher than in the PS90 and control treatments. In the exchangeable fraction, $\mathrm{Zn}$ contents in the 0-2.5, 2.5-5.0 and 5.0-10 cm layers were highest in the DL90 and DL180 treatment. But in PS180, the $\mathrm{Zn}$ contents in the exchangeable fraction, especially in the 0-2.5, 2.5-5.0 and 5.0-10 cm layers were lower than in DL90 and DL180, but higher than in PS90. In all layers, $\mathrm{Zn}$ contents in the exchangeable fraction in PS90, PS180, DL90 and DL180 were higher than in the control treatment.

The highest Zn contents linked to the clay mineral and organic matter fraction in the soil of the PS90, PS180, DL90 and DL180 treatments were detected in the surface soil layer $(0-2.5 \mathrm{~cm})$ (Table 5). The $\mathrm{Zn}$ contents in the fraction linked to clay minerals in all layers were highest in DL180, which agrees with the contents determined in the fraction linked to organic matter, but in the 0-2.5, 2.5-5.0 and 5.0-10 cm layers. The Zn contents in the fraction linked to clay minerals and organic matter in DL90, with the exception of the 5.0-10 $\mathrm{cm}$ layer in the fraction linked to clay minerals, were lower than in DL180, but higher than in PS90 and PS180. In these two treatments and in the 0-2.5 and 5.0-10 layers, the Zn contents in the fraction linked to clay minerals were greater than in the control treatment, which was repeated in the $\mathrm{Zn}$ fraction linked to the organic fraction, but only in the $0-2.5 \mathrm{~cm}$ layer.

Zinc contents in the residual fraction were equal in all soil layers of the control, PS90 and PS180 treatments (Table 5). However, in DL90, the Zn contents in the residual fraction were highest in the 0-2.5 cm layer; and in the DL180 treatment, highest contents were observed to a depth of $5.0 \mathrm{~cm}$. The highest $\mathrm{Zn}$ contents in the residual fraction in the 0 2.5, 2.5-5.0 and 10-15 cm layers were found in DL90 and DL180, but in the PS90 and PS180 treatments, the $\mathrm{Zn}$ contents in the residual fraction were equal to the control. On the other hand, the $\mathrm{Zn}$ contents in the total fraction were highest to a depth of $5 \mathrm{~cm}$ in PS90 and to $2.5 \mathrm{~cm}$ deep in the PS180, DL90 and DL180 treatments (Table 5). However, Cu contents in the total fraction were highest in the 0-2.5, 2.5-5.0 and 5.0-10 cm layers in DL180. The contents in the same fraction and layers observed in DL90 were lower than in DL180, but higher than in PS90 and PS180. Copper contents in the total fraction observed in these two treatments in the 0-2.5 and 2.5-5.0 cm layers were higher than in the control treatment. On the other hand, in the 10-15 cm layer, the $\mathrm{Zn}$ contents in the total fraction were equal among the treatments.

These data, but especially those listed in figure 2 , show that in all layers of the control treatment, the greatest percentage of $\mathrm{Zn}$ was found in the residual fraction, followed by the clay minerals and exchangeable fraction, whereas a small quantity of the trace element was observed in the solution (Figure 2 ). Nevertheless, with the application of pig slurry (PS90 and PS180) and deep litter (DL90 and DL180), the percentage of $\mathrm{Zn}$ in the residual fraction diminished in comparison with the control treatment, particularly in the three surface soil layers (0-2.5, 2.55.0 and $5.0-10 \mathrm{~cm}$ ). In these three layers, $\mathrm{Zn}$ was also linked to the residual fraction, but especially the percentage linked to clay minerals increased, followed by the exchangeable fraction, with a very small increase in the organic fraction. In the 10-15 cm layer, the residual Zn fraction, especially in DL180, DL90 and PS180, decreased in comparison with the control treatment because $\mathrm{Zn}$ increased in the fraction linked to clay minerals and exchangeable fraction. However, $\mathrm{Zn}$ in the fraction linked to clay minerals increased most markedly in the 0-2.5, 2.5-5.0 and 5.0-10 cm layers in DL180 and DL90, followed by PS180.

\section{DISCUSSION}

Extraction by EDTA is frequently used to evaluate $\mathrm{Cu}$ and $\mathrm{Zn}$ availability to plants (Brun et al., 2001). The highest $\mathrm{Cu}$ and $\mathrm{Zn}$ contents extracted by EDTA (CuEDTA and ZnEDTA) in the surface layer (0-2.5 $\mathrm{cm}$ ) (Table 3) of the soils treated with pig slurry (PS90 and PS180) and deep litter (DL90 and DL180) may be attributed to application of the organic sources of nutrients throughout the period from 2002 to 2010 on the soil surface, without incorporation, in no-tillage management. This fact is associated specifically to the binding of the trace elements to functional groups of different constituents of the mineral and organic phase (Schramel et al., 2000). However, the $\mathrm{Cu}$ and Zn migrated to a depth of $15 \mathrm{~cm}$ in the soil profile of PS180, DL90 and DL180 (Table 3), but quantities were highest in the soil of DL180, probably because deep litter has higher contents of nutrients, e.g., $\mathrm{Cu}$ and $\mathrm{Zn}$, and of dry matter (Table 2), than pig slurry. Migration of the trace elements may occur through water flow in the soil mass, through turbulent water flow in macropores and through cracks in the soil or even through bioturbation (Girotto et al., 2010). For $\mathrm{Zn}$, solute transport in the soil mass appears to be the most important mechanism since a fraction of the element tends to remain in the soil solution in free form or in soluble ion pairs (Citeau et al., 2003), but also in the exchangeable fraction (Table 5, Figure 2 ). On the other hand, the free $\mathrm{Cu}$ content in the soil solution is very low due to its high reactivity with the functional groups, above all with those of the soil organic matter (Croué et al., 2003) (Table 4, Figure 1 ). Thus, its migration in the soil profile preferentially occurs in the colloidal form and, therefore, turbulent flow and bioturbation assume great importance (Citeau et al., 2003; Girotto et al., 2010). In addition, part of the $\mathrm{Cu}$ and $\mathrm{Zn}$ may bond to organic acids of low 


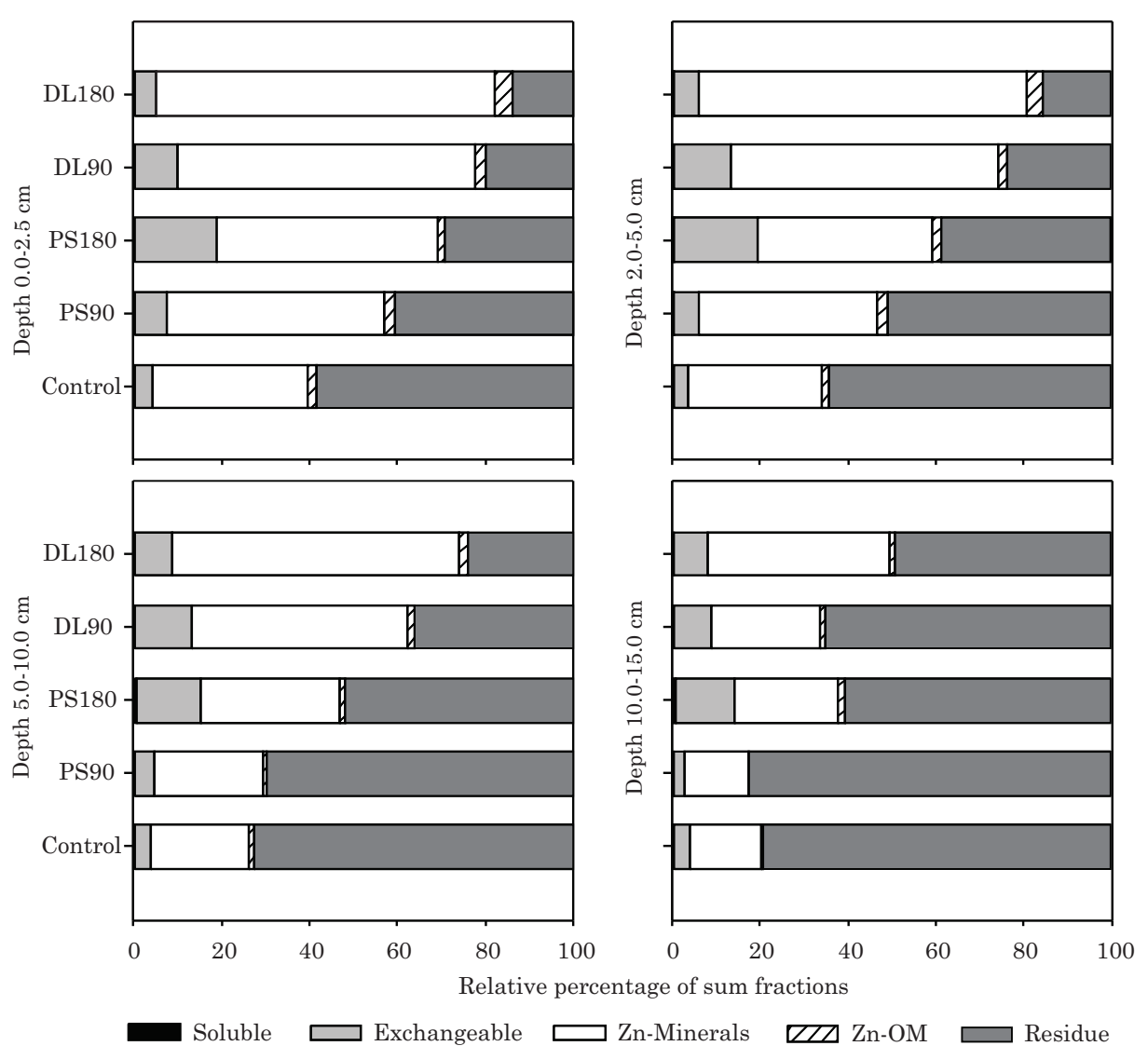

Figure 2. Relative percentage of zinc in each fraction obtained in sequential extraction in relation to the sum of the quantity extracted in soil layers subjected to applications of pig slurry and deep litter for eight years.

molecular weight, increasing mobility in the soil profile (Wang \& Mulligan, 2012). The reason could be the formation of metal complexes with organic compounds of low molecular weight changes the balance between the metals in the labile form in the solid phase and in the soil solution and can therefore also increase the release of trace elements from the solid phase and, consequently, increase their mobility in the soil (Girotto et al., 2010). Finally, mobility of $\mathrm{Cu}$ and $\mathrm{Zn}$ may have been facilitated by the sandy texture, low organic matter contents in the soil profile and the presence of clay mineral of the 1:1 type (kaolinite) in this study (Guardini et al., 2012), reducing the adsorption capacity of the two trace elements. Moreover, a reduction of the water $\mathrm{pH}$ in the deepest soil levels (Guardini et al., 2012) may also have contributed to prevent the formation of innersphere complexes between $\mathrm{Cu}$ and $\mathrm{Zn}$ and functional groups of the organic and mineral fractions, increasing their availability and, consequently, their mobility in the soil (Girotto et al., 2010).

Migration of the $\mathrm{Cu}$ and $\mathrm{Zn}$ in the soil profile may lead to contamination of underground water, especially under continuous applications of pig slurry and deep litter, as in the PS180, DL90 and DL180 treatments. Moreover, the high trace element contents in the soil, as diagnosed by CuEDTA, may lead to toxicity for plants. For example, Girotto et al. (2010) reported that a content of available $\mathrm{Cu}$ above $67.2 \mathrm{mg} \mathrm{kg}^{-1}$ extracted by EDTA from a Sandy Typic Hapludalf soil, with chemical properties similar to the soil of this study, caused physiological and biochemical stress in black oat plants 40 days after sowing, as reflected by a lower dry matter production of the above ground part. This must be avoided, since the cycling of nutrients through the cover plant species would be decreased, as well as the quantity of residues deposited on the soil surface, which are responsible for dissipating the kinetic energy of raindrops, especially in conservation systems, such as the no-till system adopted in this study.

The soluble and exchangeable $\mathrm{Cu}$ and $\mathrm{Zn}$ fractions are considered available in the soil (Tessier et al., 1979). The application of pig slurry and deep litter on the soil surface from 2002 to 2010 increased the $\mathrm{Cu}$ and especially the $\mathrm{Zn}$ contents in the soluble fractions, but to a greater extent in exchangeable fractions, somewhat more pronounced in the surface soil layers, as in the 0-2.5 and 2.5-5.0 cm layers (Tables 4 and 5, Figures 1 and 2). Nevertheless, contents were highest in the soil treated with pig deep litter throughout the years, especially in DL180 (Table 4 and 5). The liquid 
pig manure is rapidly decomposed and the released $\mathrm{Cu}$ and $\mathrm{Zn}$ increase the exchangeable fractions, quickly reaching equilibrium with the soil solution (Sposito, 1989). But the increase of the fractions of the elements in the soil is proportional to the quantity applied through manure (Girotto et al., 2010), which may be one of the explanations for the greater quantity of $\mathrm{Cu}$ and $\mathrm{Zn}$ in the solution and in the exchangeable fraction in DL180. It is worth noting that the $\mathrm{Cu}$ and the $\mathrm{Zn}$ in solution move as result of and in the direction of water flow, and may, for example, be transported to the root surface of plants where they can be absorbed (Marschner, 1995). When the concentrations of trace elements in the solution are considered adequate, they supply the plant requirements for the elements, but when the concentrations are high or even increasing over time, (for example, not only, but especially in DL180), and if the deep litter applications are continued, the trace elements, in this case $\mathrm{Cu}$ and $\mathrm{Zn}$, may reach toxic levels for plants as well as microorganisms (Ferreira et al., 2012). In addition, $\mathrm{Cu}$ and $\mathrm{Zn}$ in the solution may be transported by the soil surface runoff solution since management is a no-tillage system, which may raise the concentration of the two trace elements in surface waters adjacent to the area of application of organic residue sources, which can even make them inappropriate for consumption after some years (Ceretta et al., 2010). Furthermore, the $\mathrm{Cu}$ and the $\mathrm{Zn}$ in the solution may migrate in the soil profile, as shown by the CuEDTA and ZnEDTA data (Table 3).

The $\mathrm{Cu}$ contents in the solution increased, especially in the soil surface, down to the $2.5-5.0 \mathrm{~cm}$ layer in the treatments PS180 and DL90 and, especially, in DL180. The Zn contents in the solution increased most markedly in the $0-2.5 \mathrm{~cm}$ layer in the PS90 and DL90 treatments, as well as down to the 2.5-5.0 cm layer of DL180; the contents were lower than in the other fractions (fraction bonded to the clay minerals, organic matter and to the residual and total fractions). In addition, these contents in the soil solution, both for $\mathrm{Cu}$ and $\mathrm{Zn}$, are similar to those found by Girotto et al. (2010) in the upper layers $(0-4 \mathrm{~cm})$ of a Sandy Typic Hapludalf soil treated with 17 successive applications of $80 \mathrm{~m}^{3}$ of pig slurry in six years. The same authors report similar exchangeable $\mathrm{Cu}$ and $\mathrm{Zn}$ contents, in the same surface layers, near those obtained in this study.

Copper, especially in the surface layers (0-2.5 and $2.5-5.0 \mathrm{~cm}$ ) of soil treated with pig slurry and deep litter and also in slightly deeper layers $(5.0-10 \mathrm{~cm})$, especially in the DL180, DL90 and PS180 treatments, was more accumulated in the organic fraction of the soil (Table 5 and Figure 1), but also in the fraction linked to clay minerals, reducing its accumulation in the residual fraction. The reason was the electron configuration $[\mathrm{Ar}] 3 \mathrm{~d}^{10} 4 \mathrm{~s}^{1}$ of $\mathrm{Cu}$ and its high reactivity with the functional groups containing $\mathrm{S}$ and $\mathrm{N}$, in addition to the carboxylic and phenolic acids of soil organic matter (Croué et al., 2003; Casali et al., 2008).
Thus, the phenomenon of $\mathrm{Cu}$ adsorption to the functional groups of organic matter appears to be predominant (Girotto et al., 2010) over the fraction linked to clay minerals, especially because in the pig slurry (PS90 and PS180) and deep litter treatments (DL90 and DL180), there was an increase in total organic carbon content in the surface soil layers through the years, but particularly in DL180 (Guardini et al., 2012). Nevertheless, even with the increase of total organic carbon contents over the years, one expects saturation of the organic matter functional groups (Croué et al., 2003) and thus part of the $\mathrm{Cu}$ may be accumulated in the clay minerals. This could be an explanation for the increase in $\mathrm{Cu}$ content in the fraction linked to clay minerals also. However, the 1:1 type clay mineral (kaolinite) was predominant in the soil of this study (Guardini et al., 2012), translating to a low capacity for adsorption of trace elements (McBride, 1994) and so the distribution of $\mathrm{Cu}$ can be expected in other more available forms. In contrast to the $\mathrm{Cu}$ contents found in this study, but similar to contents in Cu-poor soils (Girotto et al., 2010 ), the $\mathrm{Zn}$, in the control originally accumulated in the residual fraction, when treated with pig slurry and deep litter, increased its percentage in the fraction linked to clay minerals and exchangeable fraction, particularly in the 0-2.5, 2.5-5.0 and 5.0-10 cm layers of DL180, DL90 and PS180. This result is consistent with the electron configuration of this trace element, which is different from $\mathrm{Cu}$ and is distributed preferentially in the mineral and exchangeable fractions in the soil (Girotto et al., 2010). These results are similar to those obtained by Girotto et al. (2010), who obtained a percentage of $70 \%$ of the sum of the $\mathrm{Zn}$ fractions linked to clay minerals in the surface layer (0-6 cm) in a Sandy Typic Hapludalf soil after 18 long-term applications of the pig slurry rate of $80 \mathrm{~m}^{3} \mathrm{ha}^{-1}$. Regardless of the fractionation arrangement used, the residual fraction represents the most stable or non-available fractions of $\mathrm{Cu}$ and $\mathrm{Zn}$ (Tessier et al., 1979). In the surface layers (0-2.5 and 2.5-5.0 cm) of pig slurry (PS90 and PS180) as well as deep litter treatments (DL90 and DL180), the residual $\mathrm{Cu}$ fractions were similar to the fractions found in the soil organic matter (Table 4 and Figure 1). However, in the deeper layers (5.0-10 and 10$15 \mathrm{~cm}$ ), the level of $\mathrm{Cu}$ in the residual fraction was greater than in the organic fraction (Figure 1). The capacity of inactivating $\mathrm{Cu}$ in the residual fraction, especially in the surface soil layers, may be attributed to the higher levels of recalcitrant organic carbon, whereas in the deeper layers, to the greater clay content, amorphous inorganic materials and clay minerals, as well as reaction time (Tessier et al., 1979; Fernández-Calviño et al., 2009). On the other hand, highest $\mathrm{Zn}$ contents in the residual fraction were found in the deeper layers (5.0-10.0 and 10.0-15 cm) and especially in the pig slurry treatments (PS90 and PS180), which may be attributed to higher contents of clay, amorphous inorganic materials and clay minerals (Fernández-Calviño et al., 2009). 


\section{CONCLUSIONS}

1. The applications of pig deep litter and slurry at doses equivalent to $90 \mathrm{~kg} \mathrm{ha}^{-1} \mathrm{~N}$ increased the contents of available $\mathrm{Cu}$ and $\mathrm{Zn}$ in the surface soil layer, if the double of this dose was applied in pig deep litter or double this dose in pig slurry, $\mathrm{Cu}$ and $\mathrm{Zn}$ migrated to a depth of $15 \mathrm{~cm}$.

2. Copper is accumulated mainly in the organic and residual fractions, and zinc preferentially in the clay mineral fraction, especially in the surface soil layers.

\section{ACKNOWLEDGEMENTS}

The authors of this work would like to thank the Social Technologies for Water Management (TSGA), Foundation for Support of Scientific and Technological Research of the State of Santa Catarina (FAPESC) and National Committee of Technological and Scientific Development (CNPq) (Edital Universal de 2011, Processo n ${ }^{\circ} 479005 / 2011-7$ ).

\section{LITERATURECITED}

BRADL, H.B. Adsorption of heavy metal ions on soils and soils constituents. Colloid Inter. Sci. 277:1-18, 2004.

BRUN, L.A.; MAILLET, J.; HINSINGER, P. \& PÉPIN, M. Evaluation of copper availability to plants in coppercontaminated vineyard soils. Environ. Pollut., 111:293$302,2001$.

CASALI, C.A.; MOTERLE, D.F.; RHEINHEIMER, D.S.; BRUNETTO, G.; CORCINI, A.L.M.; KAMINSKI, J. \& MELO, G.W.B. Formas e dessorção de cobre em solos cultivados com videira na Serra Gaúcha do Rio Grande do Sul. R. Bras. Ci. Solo, 32:1479-1487, 2008.

CERETTA, C.A.; GIROTTO, E.; LOURENZI, C.R.; TRENTIN, G.; VIEIRA, R.C.B. \& BRUNETTO, G. Nutrient transfer by runoff under no tillage in a soil treated with successive applications of pig slurry. Agric. Ecosyst. Environ., 139:689-699, 2010.

CHAIGNON, V. \& HINSINGER, P. A biotest for evaluating copper bioavailability to plants in a contaminated soil. J. Environ. Qual., 32:824-833, 2003.

CHAIGNON, V.; SANCHEZ-NEIRA, I.; HERRMANN, P.; JAILLARD, B. \& HINSINGER, P. Copper bioavailability and extractability as related to chemical properties of contaminated soils from a vine-growing area. Environ. Pollut., 123:229-238, 2003.

CITEAU, L.; LAMY, I.; VAN OORT, F. \& ELSASS, F. Colloidal facilitated transfer of metals in soils under different land use. Colloids Surf. A: Physicochem. Eng. Aspects, 217:1119, 2003.
COMISSÃO DE FERTILIDADE DO SOLO - RS/SC - CFS -RS/ SC. Recomendação de adubação e calagem para os estados do Rio Grande do Sul e Santa Catarina. $3^{\circ}$.ed. Passo Fundo, SBCS/NRS/Embrapa/CNPT, 1994. 224p.

COMISSÃO DE QUÍMICA E FERTILIDADE DO SOLO CQFS-RS/SC. Manual de adubação e calagem para os estados do Rio Grande do Sul e Santa Catarina. 10 .ed. Porto Alegre. 2004. 400 p.

CROUÉ, J.P.; BENEDETTI, M.F.; VIOLlEAU, D. \& LEENHEER, J.A. Characterization and copper binding of humic and nonhumic organic matter isolated from the South Platte River: Evidence for the presence of nitrogenous binding site. Environ. Sci. Technol., 37:328336,2003

EMPRESA BRASILEIRA DE PESQUISA AGROPECUÁRIA EMBRAPA. Manual de métodos de análise de solos. Embrapa Solos, Rio de Janeiro, 1997. 212p.

FERNÁNDEZ-CALVIÑO, D.; NÓVOA-MUÑOZ, J.C.; DÍAZRAVIÑA, M. \& ARIAS-ESTÉVEZ, M. Copper accumulation and fractionation in vineyard soils from temperate humid zone (NW Iberian Peninsula). Geoderma, 153:119-129, 2009.

FERREIRA, D. F. Programa de análises estatísticas (Statistical Analysis Software) e planejamento de experimentos. Lavras: UFLA, 2003.

FERREIRA, P.A.A.; BOMFETI, C.A.; JÚNIOR, R. S.; SOARES, B.L.; SOARES, C.R.F.S. \& MOREIRA, F.M.S. Symbiotic efficiency of Cupriavidus necator strains tolerant to zinc, cadmium, copper and lead. Pesq. Agropec. Bras., 47:8595, 2012 .

GIROTTO, E.; CERETTA, C. A.; BRUNETTO, G.; SANTOS, D. R.; SILVA, L. S.; LOURENZI, C. R.; LORENSINI, F.; RENAN VIEIRA, C. B. \& SCHMATZ, R. Acúmulo e formas de cobre e zinco no solo após aplicações sucessivas de dejeto líquido de suínos. R. Bras. Ci. Solo, 34:955-965, 2010 .

GUARDINI, R.; COMIN, J.J.; SCHMITT, D.E.; TIECHER, T.; BENDER, M.A.; DOS SANTOS, D.R.; MEZZARI, C.P.; OLIVEIRA, B.S.; GATIBONI, L.C. \& BRUNETTO, G. Accumulation of phosphorus fractions in typic Hapludalf soil after long-term application of pig slurry and deep pig litter in a no-tillage system. Nutr. Cycling Agroecosyst., 93:215-225, 2012.

MARSCHNER, H. Mineral nutrition of higher plants. 2.ed. London, Academic Press, 1995. 889 p.

McBRIDE, M.B. Environmental chemistry of soils. New York, Oxford University Press, 1994. 406p.

POPOVIC, O. \& JENSEN, L. S. Storage temperature affects distribution of carbon, VFA, ammonia, phosphorus, copper and zinc in raw pig slurry and its separated liquid fraction. Water Res., 46:3849-3858, 2012.

SCHRAMEL, O.; MICHALKE, B. \& KETTRUP, A. Study of the copper distribution in contaminated soils of hop fields by single and sequential extraction procedures. Sci. Total Environ., 263:11-22, 2000. 
SOIL SURVEY STAFF. Soil Taxonomy: A basic system of soil classification for making and interpreting soil surveys. 2 . ed. Washington DC, U.S. Government Printing Office, 1999. 871p.

SPOSITO, G. The chemistry of soils. New York, Oxford University Press, 1989. 268 p.

TEDESCO, M.J.; GIANELLO, C.; BISSANI, C. A; BOHNEN, H. \& VOLKWEISS, S. J. Análises de solo, planta e outros materiais. $2^{\circ}$.ed. Porto Alegre: UFRGS, 174p, 1995.
TESSIER, A.; CAMPBELL, P.G.C. \& BISSON, M. Sequential extraction procedure for the speciation of particulate trace metals. Anal. Chim., 51:844-851, 1979.

WANG, S. \& MULLIGAN, C. N. Effects of three low-molecularweight organic acids (LMWOAs) and $\mathrm{pH}$ on the mobilization of arsenic and heavy metals $(\mathrm{Cu}, \mathrm{Pb}$, and Zn) from mine tailings. Environ. Geochem. Health, 1-8, 2012. 